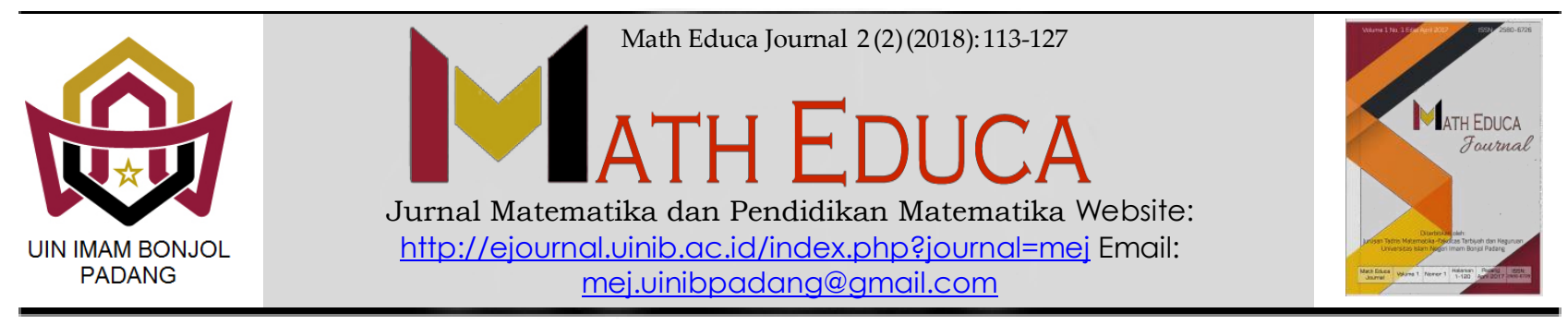

\title{
Penerapan Model Pembelajaran Kooperatif Tipe Think Talk Write Terhadap Kemampuan Penalaran Matematis Siswa Kelas XI IPA MAN Kota Padang
}

\author{
Irwan', Devi Permata Sari² \\ 1,2Tadris Matematika, Fakultas Tarbiyah dan Keguruan, UIN Imam Bonjol Padang, Indonesia \\ Email: Irwan.zj@gmail.com
}

Received: Agustus 2018; Accepted: September 2018; Published: Oktober 2018

\begin{abstract}
Abstrak
Penelitian ini berawal dari masalah rendahnya kemampuan penalaran matematis siswa kelas XI IPA MAN kota Padang. Hal ini terlihat dari hasil observasi dan analisis terhadap hasil ujian yang diberikan pada siswa. Untuk mengatasi masalah tersebut, digunakan model pembelajaran kooperatif tipe Think Talk Write. Tujuan penelitian ini adalah untuk mengetahui pengaruh penerapan model pembelajaran kooperatif tipe Think Talk Write terhadap kemampuan penalaran matematis siswa kelas XI IPA MAN kota Padang. Jenis penelitian ini adalah Quesi Experiment. Populasi penelitian ini adalah seluruh siswa kelas XI IPA MAN kota Padang. Teknik yang digunakan untuk pengambilan sampel adalah Random Sampling. Sampel pada penelitian ini adalah siswa

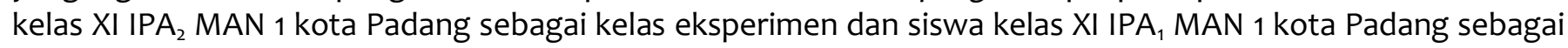
kelas kontrol. Instrumen yang digunakan adalah tes yang terdiri dari tes kemampuan awal untuk melihat kemampuan awal siswa dan tes akhir untuk melihat kemampuan penalaran matematis siswa. Hasil penelitian menunjukkan bahwa (1) Kemampuan penalaran matematis siswa yang diajar dengan model pembelajaran kooperatif tipe Think Talk Write lebih baik daripada siswa yang diajar dengan pembelajaran konvensional. (2) kemampuan penalaran matematis siswa berkemampuan awal tinggi, sedang dan rendah yang diajar dengan model pembelajaran koopetaif tipe Think Talk Write lebih baik daripada siswa yang diajar dengan pembelajaran konvensional.
\end{abstract}

Kata kunci : Model pembelajaran kooperatif tipe think talk write, Kemampuan Penalaran Matematis

\section{Abstract}

The problems that occur in the field is the low of students' mathematical reasoning abilities in the class XI IPA MAN Padang. It can be seen from the finding of observation and analysis toward the result of test given to the students. To overcome the problems, the cooperative teaching model Think Talk Write is used. The purpose of the study is to find out the effct of the cooperative teaching model Think Talk Write application toward students' mathematical reasoning abilities in the class XI IPA MAN Padang. The research is quasy experiment. The population of the research is all students in the class XI IPA MAN Padang. The technique used for the sampling is random sampling. The sample of the reasearch is the students in the class XI IPA ${ }_{2} M A N 1$ Padang as experiment class and the students in the class XI IPA, MAN 1 Padang as control class. The instrument used in the reasearch is the test that consists of the first test to see the initial ability of the students and the final test to see toward students' mathematical reasoning abilities. Based on the finding of the research, it can be concluded: first, the students' mathematical reasoning abilities which is taught by the cooperative teaching model Think Talk Write is better than those which is taught $b$ conventional teaching. Second, the students' mathematical reasoning ability

\footnotetext{
${ }^{*}$ Corresponding author.

Peer review under responsibility UIN Imam Bonjol Padang.

(C) 2018 UIN Imam Bonjol Padang. All rights reserved.

P-ISSN: 2580-6726

e-ISSN: 2598-2133
} 
who have high, fair and low abilities which is taught by the cooperative teaching model Think Talk Write is better than those which is taught $b$ conventional teaching.

Keywords: Cooperative Learnig Model Think Talk Write type ,Mathematical Reasoning Ability

\section{PENDAHULUAN}

Pembelajaran matematika adalah salah satu pembelajaran yang menjadi sarana berfikir logis, analitis, sistematis, kritis dan kreatif serta memiliki kemampuan bekerja sama dalam menghadapi berbagai masalah serta mampu memanfaatkan informasi yang diterimanya. Menurut Nasional Council of Teacher of Mathematics (NCTM, 2000: 29), dalam belajar matematika siswa dituntut untuk memiliki kemampuan: pemahaman konsep, pemecahan masalah, komunikasi, penalaran dan koneksi matematis. Hal senada juga diungkapkan Sumarmo(2000) yang menyatakan bahwa pembelajaran matematika hendaknya mengutamakan pengembangan daya matematik (mathematical power) siswa yang meliputi: kemampuan menggali, menyusun konjektur dan menalar secara logik, menyelesaikan masalah yang tidak rutin, berkomunikasi secara mate-matika dan mengaitkan ide matematika dengan kegiatan intelektual lainnya.

Kemampuan penalaran matematis merupakan kemampuan yang esensial untuk dikembangkan pada siswa sekolah menengah. Untuk itu siswa diharapkan dapat memiliki kemampuan menalarkan gagasan atau ide matematika dengan menggunakan simbol, tabel, diagram atau media lainnya serta memiliki sikap positif terhadap matematika dan percaya diri dalam memecahkan suatu masalah.

Kemampuan penalaran matematis juga diperlukan oleh siswa Madrasah Aliyah (MA). Kemampuan penalaran matematis siswa erat kaitannya dengan hasil belajar yang diperoleh oleh siswa. Berdasarkan fakta tersebut nilai rata-rata UN Matematika siswa MAN se-kota Padang dapat dilihat pada Tabel 1.

Tabel 1. Rata-Rata Nilai UN Matematika MAN se-Kota Padang 2013

\begin{tabular}{|c|c|c|}
\hline $\begin{array}{c}\text { NAMA } \\
\text { SEKOLAH }\end{array}$ & RATA-RATA & PESERTA \\
\hline MAN 1 Padang & 5,88 & 105 \\
\hline MAN 2 Padang & 5,66 & 178 \\
\hline MAN 3 Padang & 4,83 & 21 \\
\hline
\end{tabular}

Sumber: KEMENAG Sumbar

Pada Tabel 1 terlihat bahwa dari ketiga sekolah tersebut nilai rata-rata yang didapatkan masih berkisar pada nilai standar kelulusan yang ditetapkan oleh Kementerian Pendidikan dan Kebudayaan (Kemendikbud) yaitu 5,5. Dapat dikatakan bahwa nilai yang diperoleh siswa MAN se-kota Padang untuk masing-masing siswanya sebagian besar belum memuaskan. Nilai UN yang sudah dipaparkan menggambarkan bahwa siswa MAN se-kota Padang memiliki hasil belajar pada bidang studi matematika masih rendah. 
Rendahnya kemampuan penalaran matematis siswa MAN kota Padang dapat dikatakan sama karena dilihat dari nilai rata UN yang didapatkan tidak jauh berbeda. Bukti yang bisa diberikan sehubungan dengan masalah tersebut adalah siswa menjawab salah ketika diberikan soal penalaran matematis. Berikut salah satu soal dan jawaban siswa tentang kemampuan penalaran matematis.

Jika $f(x)=\frac{9}{10 x^{\frac{2}{3}}}$, maka $\lim _{p \rightarrow 0} \frac{f(x+p)-f(x)}{p}$ adalah

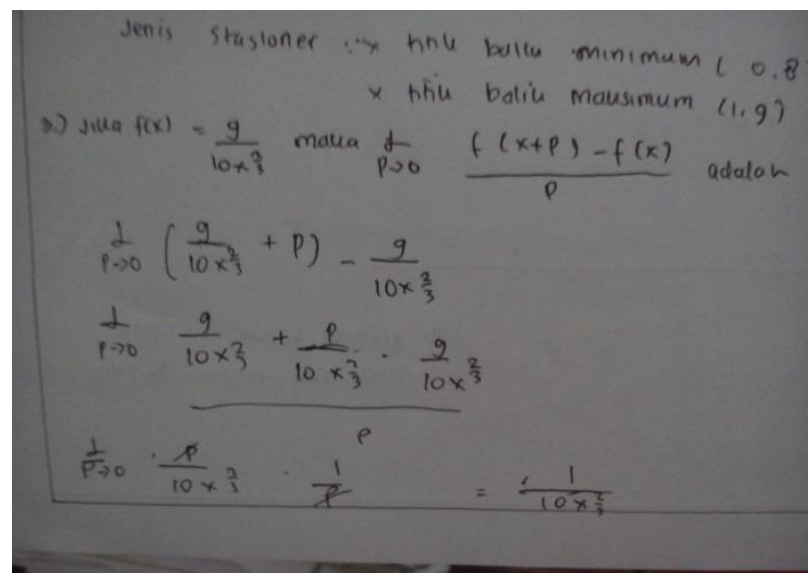

Gambar 1. Contoh Jawaban Siswa Pada Soal Tes Kemampuan Penalaran

Dari Gambar 1 terlihat bahwa siswa belum bisa menalarkan apa yang diperintahkan sesuai indikator soal yaitu menarik kesimpulan, menyusun bukti, memberikan alasan atau bukti terhadap beberapa solusi. Seharusnya siswa menjawab soal tersebut dengan menggantikan nilai $\mathrm{x}$ pada $f(x+p)$ dengan $x+p$. Sedangkan penyelesaian yang dilakukan oleh siswa seperti demikian, sehingga jawaban yang diberikan siswa belum menuju jawaban yang diharapkan. Terlihat juga pada penyelesaian soal yang dilakukan siswa kurang bisa menalarkan bentuk-bentuk fungsi apabila koefisien $\mathrm{x}$ diganti dengan yang lain.

Kemampuan Penalaran merupakan salah satu kemampuan yang harus dimiliki siswa dalam pembelajaran matematika karena merupakan salah satu bagian dari kemampuan berpikir matematika. Dalam Depdiknas (2006) juga diungkapkan bahwa kemampuan penalaran matematis merupakan salah satu tujuan pembelajaran matematika yaitu menggunakan penalaran pada pola dan sifat, melakukan manipulasi matematis dalam membuat generalisasi, menyusun bukti, atau menjelaskan gagasan dan penyataan matematis.

Menurut Kusumah (1986: 1), penalaran diartikan sebagai penarikan kesimpulan dalam sebuah argumen dan cara berpikir yang merupakan penjelasan dalam upaya memperlihatkan hubungan antara dua hal atau lebih berdasarkan sifat-sifat atau hukumhukum tertentu yang diakui kebenarannya, dengan menggunakan langkah-langkah tertentu yang berakhir dengan sebuah kesimpulan.

Sumarmo (2007: 679) mengatakan bahwa matematika mempunyai karakteristik yang menekankan pada proses deduktif yang memerlukan penalaran logis dan aksiomatik, yang mungkin diawali dengan proses induktif yang meliputi penyusunan konjektur, model matematika, analogi, dan/atau generalisasi, 
melalui pengamatan terhadap sejumlah unsur data. Sejalan dengan pendapat tersebut, secara garis besar terdapat dua jenis penalaran, yaitu penalaran induktif dan penalaran deduktif.

Berdasarkan pendapat sebelumnya dan sedikit dimodifikasi maka indikator yang digunakan untuk menilai kemampuan penalaran matematis siswa dalam penelitian ini adalah: (1) menyajikan pernyataan matematika secara lisan, tulisan, gambar, ataupun diagram, (2) mengajukan dugaan, (3) menarik kesimpulan dari pernyataan. Indikator ini diambil karena ketiga indikator tersebut dikatakan sudah bisa mencakup untuk beberapa indiktor yang lain.

Tabel 2.Rubrik Penskoran Soal Kemampuan Penalaran Matematis

\begin{tabular}{|c|c|c|c|c|c|}
\hline \multirow{2}{*}{ Indikator } & \multicolumn{5}{|c|}{ Skor } \\
\hline & 0 & 1 & 2 & 3 & 4 \\
\hline $\begin{array}{l}\text { Mengajuka } \\
\text { n dugaan } \\
\text { (conjegture } \\
\text { s). }\end{array}$ & $\begin{array}{l}\text { Tidak } \\
\text { ada } \\
\text { jawaba } \\
\text { n }\end{array}$ & \begin{tabular}{|l} 
Membu \\
at \\
dugaan \\
tidak \\
lengkap \\
dan \\
dinyata \\
kan \\
dengan \\
salah
\end{tabular} & \begin{tabular}{|l} 
Membuat \\
dugaan \\
kurang \\
lengkap \\
dan \\
sebagian \\
dinyataka \\
n dengan \\
benar
\end{tabular} & $\begin{array}{l}\text { Membua } \\
\text { t dugaan } \\
\text { lengkap } \\
\text { dan } \\
\text { sebagian } \\
\text { dinyatak } \\
\text { an } \\
\text { dengan } \\
\text { benar }\end{array}$ & $\begin{array}{l}\text { Membua } \\
\text { t dugaan } \\
\text { lengkap } \\
\text { dan } \\
\text { dinyatak } \\
\text { an } \\
\text { dengan } \\
\text { benar }\end{array}$ \\
\hline $\begin{array}{l}\text { Melakukan } \\
\text { manipulasi } \\
\text { matematika } \\
\text {. }\end{array}$ & $\begin{array}{l}\text { Tidak } \\
\text { ada } \\
\text { jawaba } \\
\text { n }\end{array}$ & \begin{tabular}{|l|} 
Ada \\
sebagia \\
n \\
manipul \\
asi \\
matema \\
tika \\
tetapi \\
dinyata \\
kan \\
dengan \\
salah
\end{tabular} & \begin{tabular}{|l} 
Ada \\
manipula \\
si \\
matemati \\
ka tetapi \\
dinyataka \\
n dengan \\
salah
\end{tabular} & \begin{tabular}{|l} 
Ada \\
manipula \\
si \\
matemat \\
ika tetapi \\
hanya \\
sebagian \\
dinyatak \\
an \\
dengan \\
benar
\end{tabular} & \begin{tabular}{|l} 
Ada \\
manipula \\
si \\
matemat \\
ika dan \\
dinyatak \\
an \\
dengan \\
benar
\end{tabular} \\
\hline
\end{tabular}

\begin{tabular}{|c|c|c|c|c|c|}
\hline $\begin{array}{l}\text { Menarik } \\
\text { kesimpulan, } \\
\text { menyusun } \\
\text { bukti, } \\
\text { memberika } \\
\text { n alasan } \\
\text { atau bukti } \\
\text { terhadap } \\
\text { beberapa } \\
\text { solusi. }\end{array}$ & \begin{tabular}{|l} 
Tidak \\
ada \\
jawaba \\
n
\end{tabular} & $\begin{array}{l}\text { Ada } \\
\text { tetapi } \\
\text { tidak } \\
\text { lengkap } \\
\text { dan } \\
\text { dinyata } \\
\text { kan } \\
\text { dengan } \\
\text { salah }\end{array}$ & \begin{tabular}{|l} 
Ada, \\
kurang \\
lengkap \\
dan \\
sebagian \\
dinyataka \\
n dengan \\
benar
\end{tabular} & $\begin{array}{l}\text { Ada, } \\
\text { lengkap } \\
\text { tetapi } \\
\text { hanya } \\
\text { sebagian } \\
\text { yang } \\
\text { dinyatak } \\
\text { an } \\
\text { dengan } \\
\text { benar }\end{array}$ & \begin{tabular}{|l} 
Ada, \\
lengkap \\
dan \\
dinyatak \\
an \\
dengan \\
benar
\end{tabular} \\
\hline
\end{tabular}

(Dimodifikasi dari Fauzan, 2011)

Berdasarkan kondisi yang telah dikemukakan sebelumnya, diterapkanlah sebuah pembelajaran yang dapat mengoptimalkan kemampuan penalaran matematis siswa yaitu dengan model pembelajaran kooperatif tipe Think Talk Write.

Model pembelajaran kooperatif tipe Think Talk Write merupakan suatu model pembelajaran yang diharapkan dapat menumbuh kembangkan kemampuan penalaran matematika siswa. Model pembelajaran kooperatif tipe TTW pada dasarnya dibangun melalui tahap think, talk, dan write. Huinker dan Laughin (1996: 82) memperkenalkan model pembelajaran kooperatif tipe TTW dengan alasan bahwa model pembelajaran ini membangun secara tepat untuk berpikir dan merefleksikan serta mengorganisasikan ide-ide serta mengetes ide tersebut sebelum siswa diminta untuk menulis.

Berdasarkan pengertian dari pembelajaran kooperatif tipe TTW dalam Wojowasito (1991:233) dinyatakan bahwa Think artinya berpikir. Dalam Kamus Besar Bahasa Indonesia berpikir artinya menggunakan akal budi untuk 
mempertimbangkan dan memutuskan sesuatu. Menurut Sardiman (2006:46) berpikir adalah aktivitas mental untuk dapat merumuskan pengertian, menyintesis dan menarik kesimpulan. Berdasarkan pengertianpengertian di atas, berpikir (Think) merupakan kegiatan mental yang dilakukan untuk mengambil keputusan misalnya merumuskan pengertian, menyintesis, dan menarik kesimpulan setelah melalui proses mempertimbangkan.

$$
\text { Dalam Wojowasito }
$$
dinyatakan Talk artinya berbicara. Sedangkan dalam Kamus Besar Bahasa Indonesia bicara artinya pertimbangan, pikiran, pendapat. Dalam Wojowasito (1991:284) dinyatakan Write artinya menulis. Dalam Kamus Besar Bahasa Indonesia menulis adalah membuat huruf, angka dan sebagainya dengan pena, pensil, kapur dan sebagainya.

Sehingga model pembelajaran kooperatif tipe TTW merupakan perencanaan dan tindakan yang cermat mengenai kegiatan pembelajaran yaitu melalui kegiatan berpikir (Think), berbicara/ berdiskusi, bertukar pendapat (Talk) dan menulis hasil diskusi (Write) agar kompetensi yang diharapkan tercapai.

Tahap pertama kegiatan siswa yang belajar dengan model pembelajaran kooperatif tipe TTW adalah Think, yaitu tahap berfikir. Aktivitas berfikir siswa dapat terlihat dari proses membaca suatu teks soal, kemudian membuat catatan kecil dari apa yang telah dibaca. Catatan siswa tersebut dibuat dengan bahasanya sendiri, berupa apa yang diketahui, dan tidak diketahui dari teks soal, serta bagaimana langkah-langkah penyelesaian masalah. Menurut Wiedehold (dalam Ansari, 2003:36) membuat catatan berarti menganalisis tujuan isi teks dan memeriksa bahan-bahan yang ditulis. Selain itu, belajar rutin membuat/menulis catatan setelah membaca dapat merangsang aktivitas berfikir sebelum, selama dan setelah membaca. Membuat catatan dapat mempertinggi pengetahuan siswa, bahkan meningkatkan keterampilan berfikir dan menulis.

Tahap kedua adalah Talk (berbicara atau diskusi). Pada tahap kedua ini, siswa berkomunikasi dengan menggunakan katakata dan bahasa yang mereka pahami. Siswa menyampaikan ide yang diperoleh pada tahap think kepada temen-teman diskusi sekelompoknya yaitu dengan membahas halhal yang diketahui dan tidak diketahuinya. Pemahaman dibangun melalui interaksinya dalam diskusi. Pada tahap ini siswa merefleksikan, menyusun, serta menguji (negosiasi, Sharing) ide-ide dalam kegiatan diskusi kelompok. Kemajuan komunikasi siswa akan terlihat pada dialognya dalam berdiskusi baik dalam bertukar ide dengan orang lain ataupun refleksi mereka sendiri yang diungkapkannya kepada orang lain. Selain itu, 
tahap ini memungkinkan siswa untuk terampil bicara.

Tahap ketiga adalah Write, siswa menuliskan ide-ide yang diperolehnya pada kegiatan tahap pertama dan kedua. Aktivitas menulis berarti mengkonstruksikan ide, karena setelah berdiskusi atau berdialog antarteman, kemudian siswa mengungkapkannya ke dalam bentuk tulisan. Tulisan ini terdiri atas landasan konsep yang digunakan, keterkaitan dengan materi sebelumnya, metode penyelesaian, dan solusi yang diperolehnya.

Kemampuan awal juga merupakan faktor yang menentukan serta mempengaruhi keberhasilan belajar matematika siswa. Memperhatikan karakterisitik matematika sebagai ilmu yang hirarki dan sistematis, maka dapat diprediksi bahwa kemampuan awal matematika siswa akan memberikan pengaruh terhadap pencapaian hasil belajar selanjutnya. Hal ini diperkuat oleh Dochy dalam Mardiana (2012: 4) tentang kemampuan awal menemukan bahwa kemampuan awal siswa berkontribusi signifikan skor-skor pasca tes atau perolehan belajar.

Kemampuan awal adalah kemampuan yang telah dimiliki oleh siswa sebagai dasar sebelum ia mengikuti pembelajaran yang akan diberikan. Kemampuan awal ini menggambarkan kesiapan siswa dalam menerima pelajaran yang akan berlangsung. Kemampuan ini dapat berupa pemahaman siswa terhadap materi awal (materi prasyarat) yang harus mereka kuasai sebelum masuk kepada materi baru. Sebelum memulai pembelajaran guru perlu mengetahui kemampuan awal siswa, karena dengan demikian dapat diketahui apakah siswa telah mempunyai pengetahuan prasyarat untuk mengikuti pembelajaran. Apabila materi awal sudah dipahami dengan baik, maka dapat disimpulkan untuk sementara bahwa untuk materi selanjutnya akan lebih mudah dipahami oleh siswa.

Berdasarkan uraian di atas perlu diteliti lebih lanjut mengenai pengaruh model pembelajaran kooperatif tipe TTW terhadap kemampuan penalaran matematis siswa. Model pembelajaran kooperatif tipe TTW menjadi pilihan karena pembelajaran ini dapat mendorong siswa untuk terlibat secara aktif dalam diskusi, bertanya serta menjawab pertanyaan, berfikir secara kritis, menjelaskan setiap jawaban yang diberikan, serta mengajukan alasan untuk setiap jawaban. Pembelajaran dalam kelompok ini menekankan pada penggunaan diskusi, baik diskusi dalam kelompok kecil maupun diskusi dalam kelas secara keseluruhan.

Dalam upaya mengefektifkan pelaksanaan model pembelajaran kooperatif tipe TTW guru berperan dan bertugas untuk mengajukan dan menyediakan tugas yang memungkinkan siswa untuk terlibat secara aktif berfikir, mendorong dan menyimak dengan hati-hati ide-ide yang dikemukakan 
oleh siswa secara lisan dan tertulis, Oleh sebab itu, dirancang suatu penelitian yang bertujuan untuk melihat sejauh mana model pembelajaran kooperatif tipe TTW dan kemampuan awal dapat berpengaruh terhadap kemampuan penalaran matematis siswa. Tujuan penelitian ini untuk mengetahui (1) kemampuan penalaran matematis siswa; (2) kemampuan penalaran matematis siswa yang memiliki kemamuan awal tinggi, sedang dan rendah.

\section{METODE PENELITIAN}

\section{Jenis Penelitian}

Jenis penelitian ini adalah eksperimen semu (quasi experiment) dengan rancangan penelitian randomized control group only design. Populasi pada penelitian ini adalah MAN kota Padang. Teknik pengambilan sampel adalah Random Sampling, dengan sampel yang terpilih adalah siswa kelas XI IPA MAN kota Padang sebagai kelas eksperimen dan siswa kelas XI IPA 1 MAN kota Padang sebagai kelas kontrol.

\section{Waktu dan Tempat Penelitian}

Penelitian ini dilaksanakan pada tanggal 28 Oktober sampai dengan 5 Desember 2013 di MAN se-kota Padang sebagai kelas eksperimen kelas XI IPA 2 MAN 1 Padang dan sebagai kelas kontrol kelas XI IPA $\mathrm{IPAN}_{1}$ Padang

\section{Subjek Penelitian}

Instrumen yang digunakan dalam pengumpulan data adalah tes kemampuan awal dan tes akhir untuk melihat kemampuan Penalaran matematis siswa. Soal tes akhir yang diberikan kepada kedua kelas sampel adalah soal yang sama. Sebelum tes kemampuan awal serta tes akhir diberikan pada kelas sampel, terlebih dahulu dilakukan uji coba terhadap kedua tes tersebut yang dilakukan di MAN 2 Kota Padang. Setelah itu dilakukan analisis validitas dan reliabilitas terhadap tes. Berdasarkan analisis tersebut diketahui bahwa tes kemampuan awal dan tes kemampuan komunikasi matematis dapat digunakan sebagai alat pengumpul data.

Pada penelitian ini kemampuan awal berperan sebagai variabel moderator. Tujuan menggunakan kemampuan awal sebagai variabel moderator adalah untuk melihat model pembelajaran kooperatif tipe TTW lebih cocok atau baik digunakan pada kelompok siswa berkemampuan awal rendah, sedang atau siswa yang memiliki kemampuan awal tinggi. Kriteria pengelompokannya seperti berikut.

Tabel 3. Kriteria Pengelompokan Kemampuan Awal

\begin{tabular}{|c|c|}
\hline Kriteria Kemampuan Awal & Keterangan \\
\hline$x \geq(\bar{x}+S D)$ & Tinggi \\
\hline$(\bar{x}-S D)<\mathrm{x}<(\bar{x}+S D)$ & Sedang \\
\hline$x \leq(\bar{x}-S D)$ & Rendah \\
\hline
\end{tabular}

Data dari tes kemampuan awal siswa digunakan untuk mengelompokkan siswa 
menjadi tiga kategori, yaitu tinggi, sedang dan rendah.

\section{Populasi dan Sampel}

Populasi dalam penelitian ini adalah siswa kelas XI IPA MAN se-Kota Padang yaitu MAN 1, MAN 2 dan MAN 3 Padang. Banyak kelas populasinya dapat dilihat pada tabel 8 .

Tabel 4. Populasi

\begin{tabular}{|c|c|c|}
\hline No & Sekolah & Jumlah Kelas \\
\hline 1 & MAN 1 Padang & 2 \\
\hline 2 & MAN 2 Padang & 5 \\
\hline 3 & MAN 3 Padang & 1 \\
\hline \multicolumn{2}{|c|}{ Jumlah kelas } & 8 \\
\hline
\end{tabular}

Karena data dari populasi telah memiliki kesamaan rata-rata, maka sampel dapat dipilih secara acak. Pengambilan sampel dilakukan dengan pengundian menggunakan gulungan kertas. Kelas yang terambil pertama

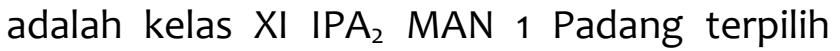
sebagai kelas eksperimen dan yang terambil berikutnya adalah kelas XI IPA 1 MAN 1 Padang terpilih sebagai kelas kontrol.

\section{Prosedur}

Desain penelitian Randomized Control Group Only Design dapat digambarkan seperti berikut:

Tabel 5. Rancangan Penelitian

\begin{tabular}{|l|c|c|}
\hline \multicolumn{1}{|c|}{ Kelas } & Perlakuan & Tes \\
\hline Eksperimen & $\mathrm{X}$ & $\mathrm{T}$ \\
Kontrol & - & $\mathrm{T}$ \\
\hline
\end{tabular}

Keterangan :

$X$ : Perlakuan dengan model kooperatif tipe TTW

T: Tes kemampuan komunikasi dan penalaran matematis
Rancangan ini akan diterapkan pada situasi yang berbeda yaitu kelas eksperimen akan diterapkan model pembelajaran kooperatif tipe think-talk-write dan kelas kontrol akan diterapkan pembelajaran konvesional. Rancangan ini akan diuraikan dalam bentuk Tabel Winner dibawah ini.

\begin{tabular}{llr} 
Tabel 6. & $\begin{array}{l}\text { Tabel Winner } \\
\text { Komunikasi dan } \\
\text { Matematis }\end{array}$ & $\begin{array}{r}\text { Kemampuan } \\
\text { Penalaran }\end{array}$ \\
\hline
\end{tabular}

\begin{tabular}{|c|c|c|}
\hline $\begin{array}{l}\text { Model } \\
\text { Pembelajaran } \\
\text { (A) } \\
\text { Pengetaharan } \\
\text { Awal (B) }\end{array}$ & $\begin{array}{c}\text { Pembelajaran } \\
\text { TTW } \\
\left(\mathrm{A}_{1}\right)\end{array}$ & $\begin{array}{l}\text { Pembelajaran } \\
\text { Konvensional } \\
\qquad\left(A_{2}\right)\end{array}$ \\
\hline Tinggi $\left(B_{1}\right)$ & $A_{1} B_{1}$ & $A_{2} B_{1}$ \\
\hline Sedang $\left(B_{2}\right)$ & $A_{1} B_{2}$ & $A_{2} B_{2}$ \\
\hline Rendah $\left(B_{3}\right)$ & $A_{1} B_{3}$ & $A_{2} B_{3}$ \\
\hline
\end{tabular}

Keterangan:

$\mathrm{A}_{1}=$ Model pembelajaran kooperatif tipe TTW

$\mathrm{A}_{2} \quad=$ Model pembelajaran konvensional

$\mathrm{B}_{1} \quad$ = Siswa berkemampuan awal tinggi

$\mathrm{B}_{2} \quad$ = Siswa berkemampuan awal sedang

$\mathrm{B}_{3} \quad=$ Siswa berkemampuan awal rendah

$\mathrm{A}_{1} \mathrm{~B}_{1}=$ Pembelajaran TTW pada kelompok siswa yang mempunyai kemampuan awal tinggi

$A_{2} B_{1}=$ Pembelajaran konvensional pada kelompok siswa yang mempunyai kemampuan awal tinggi

$\mathrm{A}_{1} \mathrm{~B}_{2}=$ Pembelajaran TTW pada kelompok siswa yang mempunyai kemampuan awal sedang

$\mathrm{A}_{2} \mathrm{~B}_{2}=$ Pembelajaran konvensional pada kelompok siswa yang mempunyai kemampuan awal sedang

$\mathrm{A}_{1} \mathrm{~B}_{3}=$ Pembelajaran TTW pada kelompok siswa yang mempunyai kemampuan awal rendah

$\mathrm{A}_{3} \mathrm{~B}_{3}=$ Pembelajaran konvensional pada kelompok siswa yang mempunyai kemampuan awal rendah 


\section{Data, Intrumen, dan Teknik Pengumpulan} Data

Jenis data yang digunakan dalam penelitian ini terdiri atas (1) Data primer, yaitu data yang diambil dari sampel melalui tes akhir untuk melihat hasil belajar siswa terhadap pembelajaran matematika yang menggunakan model pembelajaran kooperatif tipe TTW pada siswa kelas eksperimen. Sumber datanya diperoleh dari siswa kelas XI IPA yang menjadi kelas eksperimen (2) Data sekunder adalah data tentang jumlah siswa yang menjadi populasi dan data nilai ujian yang diberikan pada MAN Kota Padang. Data tersebut diperoleh dari hasil tes yang sudah peneliti lakukan sebelum pengambilan sampel.

\section{Teknik Analisis Data}

Teknik analisis data yang dilakukan dalam penelitian ini adalah uji prasyaratan analisis dan uji hipotesis.

a. Uji prasyaratan analisis

Uji prasyatan analisis adalah uji yang dilakukan sebelum melakukan uji hipotesis. Uji prasyarat ini akan menentukan uji hipotesis yang digunakan selanjutnya. Uji prasyaratan analisis yang dilakukan sebagai berikut.

\section{Uji Normalitas}

Uji normalitas bertujuan untuk melihat apakah data sampel berdistribusi normal atau tidak.Uji ini dilakukan dengan menggunakan uji Kolmogorov-Smirnov dengan menggunakan SPSS. Data berdistribusi normal jika nilai $P$ yang diperoleh lebih besar dari taraf nyata $(\alpha)$ =0,05. Dengan hipotesis sebagai berikut:

$\mathrm{H}_{\mathrm{O}} \quad$ : data berdistribusi normal

$\mathrm{H}_{1} \quad$ : data tidak berdistribusi normal

Kriteria pengujiannya adalah terima $\mathrm{H}_{\mathrm{o}}$ jika nilai Sig. $>$ taraf nyata $(\alpha=0,05)$ dan tolak $\mathrm{H}_{\mathrm{o}}$ jika sebaliknya.

2. Uji Homogenitas

Uji homogenitas variansi dilakukan terhadap data tes akhir untuk melihat apakah kedua kelompok sampel memiliki variansi yang homogen atau tidak. Untuk menguji homogenitas variansi digunakan uji Levene dengan hipotesis statistiknya adalah:

$$
\begin{aligned}
& \mathrm{H}_{0}: \sigma_{1}^{2}=\sigma_{2}^{2} \\
& \mathrm{H}_{1}: \sigma_{1}^{2} \neq \sigma_{2}^{2}
\end{aligned}
$$

Dalam penelitian ini, uji homogenitas variansi dilakukan dengan bantuan software SPSS. Kriteria pengujiannya adalah terima $\mathrm{H}_{\mathrm{o}}$ jika nilai Sig. $>$ taraf nyata $(\alpha=0,05)$ dan tolak $\mathrm{H}_{\mathrm{o}}$ jika sebaliknya.

b. Uji Hipotesis

$$
\text { Berdasarkan hipotesis yang }
$$
dikemukakan, maka teknik yang digunakan dalam menganalisis data untuk meguji hipotesis uji satu pihak,

1) Hipotesis pertama

$$
\begin{aligned}
& H_{0}: \mu B_{1}=\mu B_{2} \\
& H_{1}: \mu B_{1}>\mu B_{2}
\end{aligned}
$$

2) Hipotesis kedua

$$
\begin{aligned}
& H_{0}: \mu A_{1} B_{1}=\mu A_{1} B_{2} \\
& H_{1}: \mu A_{1} B_{1}>\mu A_{1} B_{2}
\end{aligned}
$$

3) Hipotesis ketiga

$$
\begin{aligned}
& H_{0}: \mu A_{2} B_{1}=\mu A_{2} B_{2} \\
& H_{1}: \mu A_{2} B_{1}>\mu A_{2} B_{2}
\end{aligned}
$$


4) Hipotesis keempat

$$
\begin{aligned}
& H_{0}: \mu A_{3} B_{1}=\mu A_{3} B_{2} \\
& H_{1}: \mu A_{3} B_{1}>\mu A_{3} B_{2}
\end{aligned}
$$

\section{HASIL PENELITIAN DAN PEMBAHASAN}

Data kemampuan penalaran matematis siswa diperoleh melalui tes akhir. Skor tes akhir kemampuan penalaran matematis siswa kelas eksperimen dan kelas kontrol berdasarkan kemampuan awal siswa. Hasil analisis tes akhir kemampuan penalaran matematis dapat dilihat pada Tabel 7.

Tabel 7. Hasil Analisis Data Tes Kemampuan

\begin{tabular}{|c|c|c|c|c|c|c|c|}
\hline \multirow{2}{*}{ Kelas } & \multirow{2}{*}{$\begin{array}{l}\text { Kem. } \\
\text { Awal }\end{array}$} & \multirow{2}{*}{$\mathbf{N}$} & \multicolumn{5}{|c|}{ Skor Tes Akhir } \\
\hline & & & $\overline{\boldsymbol{x}}$ & $s$ & $s^{2}$ & $\mathbf{X}_{\max }$ & $X_{\min }$ \\
\hline \multirow{4}{*}{$\begin{array}{l}\text { Ekspe } \\
\text { rimen }\end{array}$} & Tinggi & 7 & 10 & 1,07 & 1,14 & 12 & 9 \\
\hline & Sedang & 27 & $\begin{array}{c}8,4 \\
5 \\
\end{array}$ & 1,47 & 2,17 & 11 & 6 \\
\hline & \begin{tabular}{|l} 
Rendah \\
\end{tabular} & 4 & 8,5 & 1,5 & 2,25 & 10 & 6 \\
\hline & Total & 38 & $\begin{array}{c}8,7 \\
4 \\
\end{array}$ & 1,53 & 2,35 & 12 & 6 \\
\hline \multirow{4}{*}{$\begin{array}{c}\text { Kon- } \\
\text { trol }\end{array}$} & Tinggi & 6 & 8,5 & 1,81 & 3,25 & 11 & 5 \\
\hline & Sedang & 27 & 7,29 & 1,29 & 1,69 & 10 & 5 \\
\hline & Rendah & 7 & 6,72 & 1,03 & 1,06 & 8 & 5 \\
\hline & Total & 40 & $\begin{array}{c}7,3 \\
8\end{array}$ & 1,44 & $\begin{array}{c}2,0 \\
8\end{array}$ & 11 & 5 \\
\hline
\end{tabular}
Penalaran Matematis

Untuk kemampuan penalaran matematis berdasarkan kemampuan awal, rata-rata skor kemampuan penalaran matematis siswa yang berkemampuan awal tinggi, sedang dan rendah kelas eksperimen lebih tinggi dibandingkan rata-rata skor kelas kontrol. Variansi dan simpangan baku skor tes akhir siswa kelas eksperimen yang berkemampuan awal tinggi lebih rendah dibandingkan dengan kelas kontrol, sedangkan untuk kemampuan awal sedang dan rendah variansi dan simpangan baku kelas eksperimen lebih tinggi daripada kelas kontrol. Hal ini berarti kemampuan penalaran matematis siswa kelas kontrol yang berkemampuan awal tinggi lebih beragam daripada kelas eksperimen berkemampuan awal tinggi, sedangkan untuk kemampuan penalaran matematis siswa berkemampuan awal sedang dan rendah kelas eksperimen lebih beragam daripada kelas kontrol.

\section{Pengujian Prasyarat analisis}

Uji normalitas distribusi data kemampuan penalaran matematis siswa kelas eksperimen dan kelas kontrol menggunakan uji kolmogorof-smirnov. Kriteria pengujiannya adalah terima $\mathrm{H}_{\mathrm{o}}$ jika nilai sig > taraf nyata ( $\alpha=0,05)$ dan tolak $\mathrm{H}_{\mathrm{o}}$ jika sebaliknya. Hasil uji normalitas distribusi data kemampuan penalaran matematis siswa kelas eksperimen dan kelas kontrol dapat dilihat pada tabel 8 berikut.

Tabel 8. Hasil Uji Normalitas Distribusi Data Kemampuan Penalaran Matematis

\begin{tabular}{|c|c|c|c|}
\hline $\begin{array}{c}\text { Kelas } \\
\text { sampel }\end{array}$ & $\begin{array}{c}\text { Kemampu } \\
\text { an awal }\end{array}$ & $\begin{array}{c}\text { Nilai } \\
\text { sig. }\end{array}$ & Keterangan \\
\hline \multirow{3}{*}{$\begin{array}{c}\text { Kelas } \\
\text { Eksperimen }\end{array}$} & Tinggi & 0,200 & Normal \\
\cline { 2 - 4 } & Sedang & 0,057 & Normal \\
\cline { 2 - 4 } & Rendah & 0,000 & Tidak Normal \\
\cline { 2 - 4 } & Total & 0,006 & Tidak Normal \\
\hline \multirow{3}{*}{$\begin{array}{c}\text { Kelas } \\
\text { Kontrol }\end{array}$} & Tinggi & 0,200 & Normal \\
\cline { 2 - 4 } & Sedang & 0,020 & Tidak Normal \\
\cline { 2 - 4 } & Rendah & 0,200 & Normal \\
\cline { 2 - 4 } & Total & 0,007 & Tidak normal \\
\hline
\end{tabular}

Tabel 8 menunjukkan bahwa tidak semua nilai data kemampuan penalaran matematis siswa kelas eksperimen dan kelas kontrol mempunyai nilai sig. Lebih besar dari taraf nyata $(\alpha=0,05)$. Secara garis besar nilai sig. Kelas eksperimen sebanding dengan nilai 
sig. Kelas kontrol. Ditinjau dari nilai sig. data kemampuan penalaran matematis berdasarkan kemampuan awal diperoleh bahwa nilai sig. siswa kelas eksperimen berkemampuan awal tinggi dan sedang serta siswa kelas kontrol yang berkemampuan awal tinggi dan rendah memiliki nilai sig. > 0,05 yang berarti terima $H_{0}$ sedangkan siswa kelas eksperimen berkemampuan awal rendah serta kelas kontrol yang berkemampuan awal sedang memiliki nilai sig $<0,05$ yang berarti tolak $\mathrm{H}_{\mathrm{o}}$. Dengan demikian dapat disebutkan bahwa data kemampuan penalaran matematis siswa kelas eksperimen berkemampuan awal tinggi dan sedang serta kelas kontrol yang berkemampuan awal tinggi dan rendah berdistribusi normal sedangkan untuk data siswa kelas eksperimen berkemampuan awal rendah serta siswa kelas kontrol berkemampuan awal sedang tidak berdistribusi normal.

Uji homogenitas variansi data kemampuan penalaran matematis siswa kelas eksperimen dan kelas kontrol menggunakan uji levene. Kriteria pengujiannya adalah terima $\mathrm{H}_{\mathrm{o}}$ jika nilai sig $>$ taraf nyata $(\alpha=0,05)$ dan tolak $\mathrm{H}_{\mathrm{o}}$ jika sebaliknya.

\section{Pengujian Hipotesis Pertama}

Uji hipotesis ini digunakan untuk mengetahui kemampuan penalaran matematis siswa yang diajar dengan model pembelajaran kooperatif tipe TTW pada kelas eksperimen dan pembelajaran konvensional pada kelas kontrol. Berikut disajikan hasil uji hipotesis pertama dengan menggunakan uji mannwithney seperti pada Tabel 9.

Tabel 9. Hasil Perhitungan uji mann-withney Kemampuan Penalaran Matematis siswa

\begin{tabular}{|c|c|c|}
\hline Kelas & $\mathbf{N}$ & Sig. \\
\hline Eksperimen & 38 & \multirow{2}{*}{0,000} \\
\hline Kontrol & 40 & \\
\hline
\end{tabular}

Pada Tabel 9 terlihat bahwa kemampuan penalaran matematis mempunyai nilai Sig. lebih kecil dari taraf nyata $(\alpha=0,05)$ berarti terima $\mathrm{H}_{1}$. Hal ini berarti kemampuan penalaran matematis siswa yang diajar dengan model pembelajaran kooperatif tipe TTW lebih baik daripada kemampuan penalaran matematis siswa yang diajar dengan pembelajaran konvensional.

\section{Pengujian Hipotesis Kedua}

Uji hipotesis ini digunakan untuk mengetahui kemampuan penalaran matematis siswa berkemampuan awal tinggi yang diajar dengan model pembelajaran kooperatif tipe TTW pada kelas eksperimen dan pembelajaran konvensional pada kelas kontrol. Berikut disajikan hasil uji hipotesis kedua dengan menggunakan uji t seperti pada Tabel 10.

Tabel 10. Hasil Perhitungan uji t Kemampuan Penalaran Matematis Berkemampuan Awal Tinggi

\begin{tabular}{|c|c|c|}
\hline Kelas & N & Sig. \\
\hline Eksperimen & 7 & \multirow{2}{*}{0,008} \\
\hline Kontrol & 6 & \\
\hline \multicolumn{2}{|c|}{ Pada Tabel 10 terlihat bahwa }
\end{tabular}

kemampuan penalaran matematis mempunyai nilai Sig. lebih kecil dari taraf nyata $(\alpha=0,05)$ berarti terima $\mathrm{H}_{1}$. Hal ini berarti kemampuan 
penalaran matematis siswa berkemampuan awal tinggi yang diajar dengan model pembelajaran kooperatif tipe TTW lebih baik daripada kemampuan penalaran matematis siswa berkemampuan awal tinggi yang diajar dengan pembelajaran konvensional.

\section{Pengujian Hipotesis Ketiga}

Uji hipotesis ini digunakan untuk mengetahui kemampuan penalaran matematis siswa berkemampuan awal sedang yang diajar dengan model pembelajaran kooperatif tipe TTW pada kelas eksperimen dan pembelajaran konvensional pada kelas kontrol.Berikut disajikan hasil uji hipotesis ketiga dengan menggunakan uji $t$ seperti pada Tabel 11.

Tabel 11. Hasil Perhitungan Uji t Kemampuan Penalaran Matematis Berkemampuan Awal Sedang

\begin{tabular}{|c|c|c|}
\hline Kelas & N & Sig. \\
\hline Eksperimen & 27 & \multirow{2}{*}{0,0045} \\
\hline Kontrol & 27 & \\
\hline \multicolumn{2}{|c|}{ Pada Tabel 11} & terlihat bahwa
\end{tabular}

kemampuan penalaran matematis mempunyai nilai Sig. lebih kecil dari taraf nyata $(\alpha=0,05)$ berarti terima $\mathrm{H}_{1}$. Hal ini berarti kemampuan penalaran matematis siswa berkemampuan awal sedang yang diajar dengan model pembelajaran kooperatif tipe TTW lebih baik daripada kemampuan penalaran matematis siswa berkemampuan awal sedang yang diajar dengan pembelajaran konvensional.

\section{Pengujian Hipotesis Keempat}

Uji hipotesis ini digunakan untuk mengetahui kemampuan penalaran matematis siswa berkemampuan awal rendah yang diajar dengan model pembelajaran kooperatif tipe TTW pada kelas eksperimen dan pembelajaran konvensional pada kelas kontrol.Berikut disajikan hasil uji hipotesis keempat dengan menggunakan uji Mann-Wtihney seperti pada Tabel 12.

Tabel 12. Hasil Perhitungan mann-withney Kemampuan Komunikasi Matematis Berkemampuan Awal Rendah

\begin{tabular}{|c|c|c|}
\hline Kelas & $\mathbf{N}$ & Sig. \\
\hline Eksperimen & 4 & \multirow{2}{*}{0,049} \\
\hline Kontrol & 7 & \\
\hline
\end{tabular}

kemampuan penalaran matematis mempunyai nilai Sig. lebih kecil dari taraf nyata $(\alpha=0,05)$ berarti terima $\mathrm{H}_{1}$. Hal ini berarti kemampuan penalaran matematis siswa berkemampuan awal rendah yang diajar dengan model pembelajaran kooperatif tipe TTW lebih baik daripada kemampuan penalaran matematis siswa berkemampuan awal rendah yang diajar dengan pembelajaran konvensional.

Indikator pertama dalam kemampuan penalaran matematis siswa adalah Mengajukan dugaan (conjegture). Pada indikator ini siswa diminta untuk membuat dugaan sebelum mereka membuat penyelesaian soal. Penyelesaian yang diberikan oleh siswa kelas eksperimen sudah tercapai dengan baik karena siswa kelas eksperimen sudah dibiasakan untuk membuat dugaan dalam menyelesaikan masalah yang ada dalam LKS. Penyelesaian yang dibuat oleh siswa benar seperti yang terlihat pada Gambar 2. 


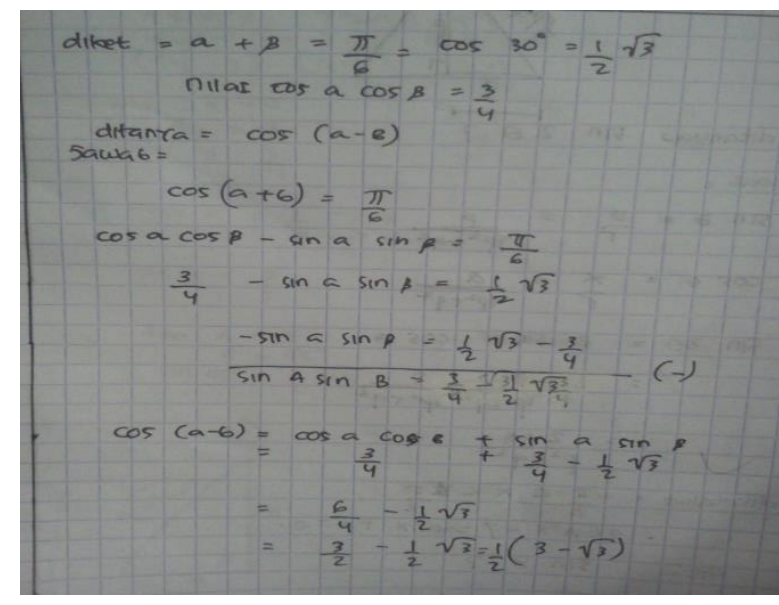

Gambar 2. Jawaban Soal Kemampuan Penalaran Indikator Pertama Kelas Eksperimen

Pada hasil kemampuan penalaran matematis siswa kelas kontrol untuk indikator yang pertama menunjukkan hasil yang sama. Siswa kelas kontrol juga melakukan hal yang sama dengan siswa kelas eksperimen, ada beberapa siswa yang sudah menyajikan gambar tapi masih keliru dalam menyelesaikan soal. Hal ini terjadi karena siswa tersebut belum memahami maksud atau tujuan dari soal seperti yang terlihat pada gambar 3 .

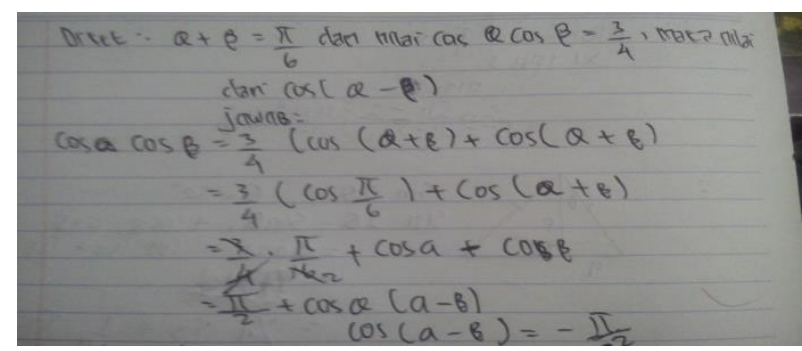

\section{Gambar 3. Jawaban Soal Kemampuan Penalaran Indikator Pertama Kelas Kontrol}

Indikator kedua dalam kemampuan penalaran matematis siswa adalah melakukan manipulasi matematika. Pada indikator ini siswa diminta untuk melakukan manipulasi sebelum mereka membuat penyelesaian soal. Sama halnya dengan indikator yang pertama terdapat siswa yang kelupaan melakukan manipulasi jawaban mereka padahal siswa kelas eksperimen sudah dibiasakan untuk membuat manipulasi dalam menyelesaikan masalah yang ada dalam LKS. Jawbaan siswa seperti yang terlihat pada Gambar 4.

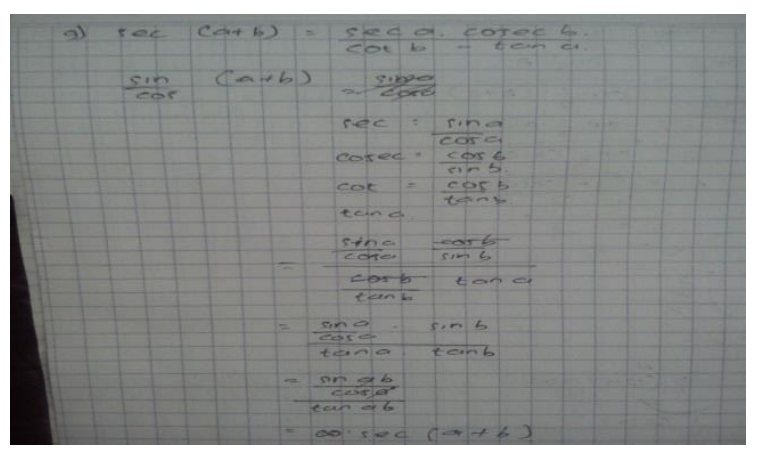

Gambar 4. Jawaban Soal Kemampuan Penalaran Indikator Kedua Kelas Eksperimen

Pada Gambar 14 terlihat bahwa jawaban siswa tersebut sudah tepat sesuai dengan manipulasi yang diharapakan. Pada indikator ini soal yang diberikan oleh guru berupa sebuah bentuk pembuktian yang butuh kemampuan manipulasi untuk mendapatkan jawbannya. Dengan demikian, karena sebagian besar siswa sudah mencoba untuk melakukan manipulasi, mengakibatkan rata-rata skor siswa untuk indikator melakukan manipulasi mendekati nilai yang diharapkan. Namun terjadi sebaliknya pada kelas kontrol, sebahagian besar siswa tidak melakukan manipulasi. Hal ini mengakibatkan rata-rata skor siswa untuk indikator melakukan manipulasi kelas eksperimen lebih tinggi jika dibandingkan dengan kelas kontrol.

Indikator ketiga dalam kemampuan penalaran matematis siswa adalah Menarik kesimpulan, menyusun bukti, memberikan 
alasan atau bukti terhadap beberapa solusi. Pada indikator ini siswa dituntut untuk membuat suatu kesimpulan atau keputusan dari pernyataan yang diminta oleh soal yang diberikan. Pada indikator ini masih banyak siswa kelas eksperimen yang tidak membuat kesimpulan serta membuktikan, begitu juga dengan siswa kelas kontrol. Hal ini juga dapat dilihat dari jawaban siswa kelas eksperimen dan kelas kontrol dalam menyelesaikan soal untuk indikator keempat seperti pada Gambar 5 dan Gambar 6.

Pada gambar 5 dan gambar 6 terlihat bahwa jawaban siswa kelas eksperimen dan kelas kontrol sudah benar namun siswa tidak membuatkan kesimpulan diakhir jawabannya Jika dilihat secara keseluruhan, jawaban yang dibuat siswa kelas eksperimen dan kelas kontrol untuk indikator ketiga sebagian besar masih kurang tepat. Perolehan akhir rata-rata skor tes akhir kemampuan penalaran siswa kelas eksperimen untuk indikator keempat lebih tinggi dari pada kelas kontrol.

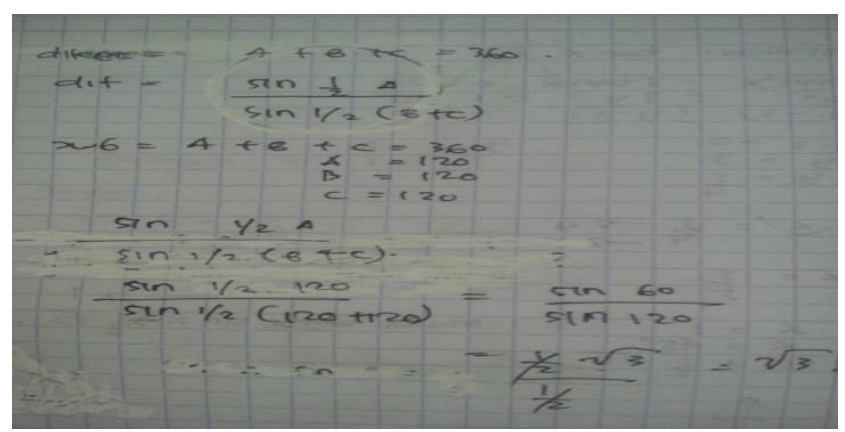

Gambar 5. Jawaban Soal Kemampuan Penalaran Indikator Ketiga Siswa Kelas Eksperimen

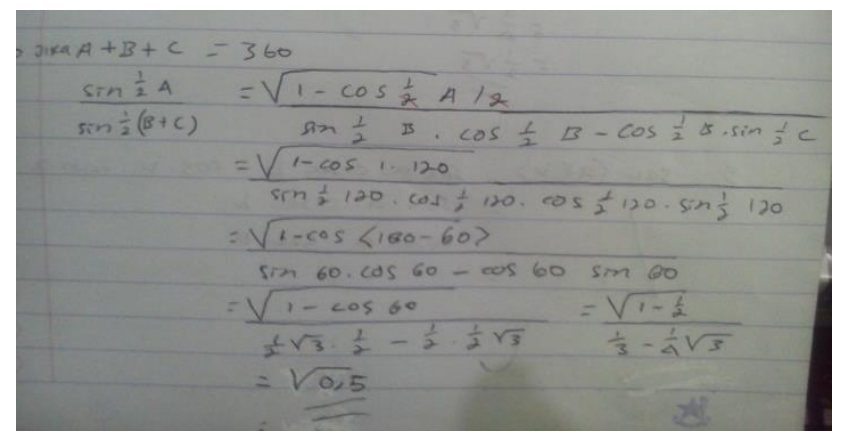

Gambar 6. Jawaban Soal Kemampuan Penalaran Indikator Ketiga Siswa Kelas Kontrol

Berdasarkan uraian yang telah dijelaskan, dapat dikatakan bahwa hal-hal-hal tersebutlah yang merupakan penyebab terjadinya kemampuan penalaran matematis siswa yang diajar dengan model kooperatif tipe TTW lebih baik daripada kemampuan penalaran matematis siswa yang diajar dengan pembelajaran konvensional.

\section{SIMPULAN DAN SARAN}

\section{Simpulan}

Berdasarkan hasil analisis data dan pembahasan, diperoleh kesimpulan bahwa a) Kemampuan penalaran matematis siswa yang diajar dengan model pembelajaran kooperatif tipe TTW lebih baik secara signifikan dari yang diajar dengan pembelajaran konvensional b) Kemampuan penalaran matematis siswa berkemampuan awal tinggi yang diajar dengan model pembelajaran kooperatif tipe TTW lebih baik secara signifikan dari yang diajar dengan pembelajaran konvensional c) Kemampuan penalaran matematis siswa berkemampuan awal sedang yang diajar dengan model pembelajaran kooperatif tipe TTW lebih baik 
secara signifikan dari yang diajar dengan pembelajaran konvensional, d) Kemampuan penalaran matematis siswa berkemampuan awal rendah yang diajar dengan model pembelajaran kooperatif tipe TTW lebih baik secara signifikan dari yang diajar dengan pembelajaran konvensional.

\section{Saran}

Saran yang dapat dikemukakan setelah dilakukan penelitian ini, yaitu kepada guru matematika MAN kota Padang diharapkan dapat menggunakan model pembelajaran kooperatif tipe TTW dalam kegiatan pembelajaran, namun untuk imple-mentasinya mungkin tidak akan sama tetapi tergantung dengan faktor lainnya.

Bagi peneliti lainnya yang tertarik untuk melakukan penelitian yang sama, untuk perlu penelitian lebih lanjut mengenai implementasi model pembelajaran kooperatif tipe TTW ini pada pokok bahasan lain. Karena pembelajaran kooperatif tipe TTW membutuhkan waktu yang cukup lama dan pengelolaan kelas yang baik, maka diharapkan untuk peneliti berikutnya dapat mengguna-kan waktu seefisien mungkin.

\section{REFERENSI}

Baroody, A.J. (1993). Problem Solving, Reasoning, and Communica-ting, $\mathrm{K}-8$ Helping Children Think Mathematically. New York: Macmillan Publishing Company.
Depdiknas. (2006). Permendiknas No.2 tentang SI dan SKL. Jakarta: Sinar Grafika.

Huinker, D.A. dan Laughin, C. (1996). "Talk Your Way into Writing". Dalam Communication in mathematics $\mathrm{K}-12$ and Beyond,1996 yearbook. The National Council of Teacher of mathematics.

Muliyardi. (2002). Strategi Pembelajaran Matematika. Padang: FMIPA UNP.

NCTM. (1989). Curriculum and Eva-lution Standars for School Mathematics. Reston, VA: NCTM

Slameto. 2003. Belajar dan factor-faktor yang mempengaruhinya. Jakarta: Rineka Cipta

Slavin, Robert, E. 2005. Cooperative Learning Teori, Riset dan Praktik. Bandung: Nusa Media

Sumarmo, U. (2007). Pembelajaran Matematika. Dalam Rujukan Filsafat, Teori, dan Praktis Ilmu Pendidikan. Bandung: Universitas Pendidikan Indonesia Press.

Toeti Soekamto \& Udin S. Winataputra. (1995). Teori Belajar dan Model-Model Pembelajaran. Jakarta: Ditjen Dikti, Depdiknas

Yamin, M dan Bansu, A. (2008). Taktik Mengembangkan Kemampuan Individu Siswa. Jakarta : Gaung Persada Press.

Walpole.E. Ronald.1992. Pengantar Statistika. Jakarta: PT Gramedia Pustaka Utama

Winkel, W. S. 1996. Psikologi Pengajaran. Jakarta: Gramedia. 